\title{
Doll's eyes
}

Arya Shah

Neurology ${ }^{\circledR}$ 2018;90:659. doi:10.1212/WNL.0000000000005253

I never realized how natural the doll's eyes reflex is until I was struck by its absence in a patient being assessed for brain death.

In my first personal encounter with death, I learned that mortality isn't an isolated fate of the old. By the time I met this teenage boy, I knew he existed in a world separate from my own. Twenty-four hours earlier, the boy's eyes had been dynamic, sparkling, mobile globes, overflowing with excitement for what the day's hike had in store. The hike led to a fall. The fall led to an infection, seizures, and intracranial hypertension. As his brain swelled, any bit of life that remained in him began to slip away.

By the time we met, his cold, blue eyes were frozen, paralyzed in a perpetual piercing stare. I shot ice cold water into his ears. I pinched his hands and feet in the hopes that he'd suddenly wake up and slap me silly. I denied him his ventilator in the hopes that he'd let out a gasp and come back to my world. I moved his head right and left and his eyes followed, so unlike the doll's eyes I was used to seeing. As we made our way down the checklist of death, he fulfilled every criterion.

Then came the whispering around conference tables, the heart-wrenching conversations with family members behind closed doors: it was almost as if he could hear us talking about pulling the plug and we couldn't bear to have him know our plan. After all, we all knew that there was only one outcome for someone who had passed the checklist of death: we had no choice but to make arrangements to time his very last breath.

Once the decision had been made, I watched as the boy's room filled with people who loved him. Friends and family circled around him and began to sing. As I listened to their voices fill the ward, I noticed his intracranial pressures start to decline. My eyes got wide, my mouth fell open, and I turned to ask the nurse next to me if it meant what I hoped it meant: that the swelling was better, that the pressure in his brain was resolving, that soon he'd wake up and all of this would eventually represent a distant memory. However, when I met the nurse's eyes, I noticed they were glistening.

I learned that day that such a pressure change meant the brain was failing, pushing further down the foramen magnum and in its wake leaving no hint of the living, breathing being the boy had been only days before. What I witnessed wasn't a miraculous improvement in intracranial pressures. It was the undeniable invasion of emptiness, slithering in and obliterating any remaining hint of what made the boy who he had been. I was watching him die.

In our field of work, there is a checklist of death. It's a test used only on select patients. However, it represents a universal truth: that mortality is a fate just as much ours as it was that boy's.

\section{Correspondence}

Arya Shah

shah.arya@mayo.edu

\section{MORE ONLINE}

\section{ค Audio}

Listen to Arya Shah read this story.

NPub.org/ipwfmo 


\section{Neurology}

Doll's eyes

Arya Shah

Neurology 2018;90;659

DOI 10.1212/WNL.0000000000005253

\section{This information is current as of April 2, 2018}

\section{Updated Information \& Services}

\section{Subspecialty Collections}

\section{Permissions \& Licensing}

\section{Reprints}

including high resolution figures, can be found at: http://n.neurology.org/content/90/14/659.full

This article, along with others on similar topics, appears in the following collection(s):

\section{Brain death}

http://n.neurology.org/cgi/collection/brain_death

\section{Coma}

http://n.neurology.org/cgi/collection/coma

Other Education

http://n.neurology.org/cgi/collection/other_education

Information about reproducing this article in parts (figures,tables) or in its entirety can be found online at:

http://www.neurology.org/about/about_the_journal\#permissions

Information about ordering reprints can be found online: http://n.neurology.org/subscribers/advertise

Neurology ${ }^{\circledR}$ is the official journal of the American Academy of Neurology. Published continuously since 1951, it is now a weekly with 48 issues per year. Copyright (O 2018 American Academy of Neurology. All rights reserved. Print ISSN: 0028-3878. Online ISSN: 1526-632X.

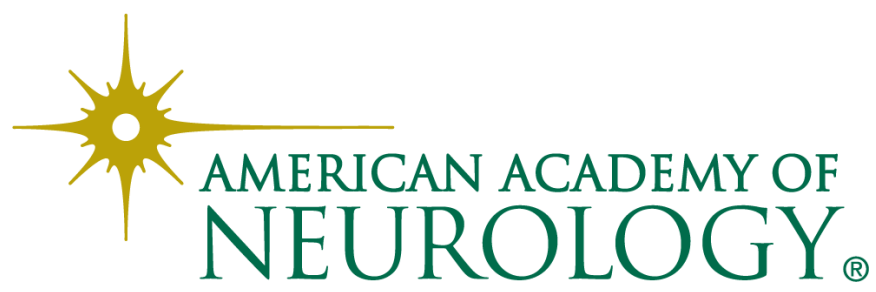

